\title{
PENGARUH DINAMIKA GUGUR DAUN TERHADAP KERAGAMAN HASIL LATEKS BEBERAPA GENOTIPE KARET HARAPAN HASIL PERSILANGAN 1992 DI PENGUJIAN PLOT PROMOSI
}

\author{
The Effect of Leaf Fall Dynamics to Latex Yield Variation in Some Promising Rubber Genotypes of Crossink \\ Result 1992 in Plot Promotion Trial
}

Sayurandi ${ }^{1}$, Desta Wirnas ${ }^{2}$, dan Sekar Woelan ${ }^{3}$

${ }^{1}$ Balai Penelitian Sungei Putih, Pusat Penelitian Karet

P.O. Box 1415, Medan 20001

${ }^{2}$ Program Studi Agronomi dan Hortikultura, Fakultas Pertanian,

Institut Pertanian Bogor, Jl. Meranti No. 1, Bogor 16680

${ }^{3}$ Pusat Penelitian Karet, J1. Salak No.1 Bogor 16151

Email: sayurandi_sp@yahoo.com

Diterima 2 Agustus 2016 / Direvisi 27 April 2017 / Disetujui 2 mei 2017

\begin{abstract}
Abstrak
Tanaman karet menggugurkan daun secara periodik akibat cekaman kekeringan yang terjadi pada bulan-bulan kering setiap tahunnya. Pada umumnya gugur daun di Provinsi Sumatera Utara terjadi pada bulan Januari sampai bulan Maret. Tujuan penelitian ini adalah untuk mengamati keragaman hasil lateks beberapa genotipe karet harapan hasil persilangan 1992 di pengujian Plot Promosiakibat dinamika gugur daun. Penelitian ini dilakukan pada bulan Agustus 2015 - Maret 2016 di Kebun Percobaan Balai Penelitian Sungei Putih, Pusat Penelitian Karet yang terletak di Kabupaten Deli Serdang. Materi genetik yang digunakan pada penelitian ini yaitu sebanyak 15 genotipe karet harapan berasal hasil persilangan 1992 Plot Promosi dengan 2 klon PB 260 dan RRIC 100 pada umur sebelas tahun. Hasil penelitian menunjukkan bahwa keragaman hasil lateks dipengaruhi oleh kondisi fase perdaunan sebagai akibat perubahan pola curah hujan bulanan. Genotipe nomer HP 92/542 memiliki hasil lateks paling tinggi pada semua fase perdaunan, sedangkan paling rendah terdapat pada genotipe HP nomer 92/677 dan HP 92/726. Berdasarkan kondisi fase perdaunan menunjukkan bahwa rerata hasil lateks paling tinggi terdapat pada saat tanaman
\end{abstract}

dalam fase daun penuh. Penurunan hasil lateks secara nyata terjadi pada saat kondisi gugur daun total dan pembentukan daun muda. Persentase penurunan hasil lateks pada kondisi tersebut masing-masing adalah $71,46 \%$ dan $73,23 \%$ terhadap fase daun penuh.

Kata kunci: Hevea brasiliensis, genotipe karet, gugur daun, keragaman hasil lateks

\section{Abstract}

Rubber trees shed their leaves periodically due to drought that occurred in dry months every year. Generally, the leaffall in North Sumatra Province occurs in January to March or April. The objective of the research to observe the latex yield variation of promising rubber genotypes of crossing result 1992 in Plot Promotion Trial effect to leaf fall dynamics. The research had been conducted in August 2015 - March 2016 at Experimental Station Sungei Putih Research Centre, Indonesian Rubber Research Institute located in Deli Serdang District. The genetic materials used in this research were 15 promising rubber genotypes of crossink result 1992 in plot promotion trial with PB 260 and RRIC 100 as control clones on eleven year old. The research result showed that the latex yield variation was influenced by leaf phase conditions as effect monthly rainfall change. Genotype number HP 92/542 had the highest latex yield on 
all of leaf phases, while genotypes number HP 92/677 and HP 92/726 had the lowest latex yield. Based on the leaf phase condition showthat average of latex yield was the highest at the trees of full leaf phase. The latex yield decreased significantly on the phase of totally leaf fall and leafinitiation phases. The percentage of latex yield decreasing to full leaf phase were $71.46 \%$ and $73.23 \%$ respectively.

Keywords: Hevea brasiliensis, promising rubber genotyp, leaffall dynamic, latex yield variation

\section{Pendahuluan}

Klon karet unggul berdaya hasil tinggi merupakan salah satu komponen teknologi penting dalam menentukan keberhasilan budidaya tanaman karet. Produksi karet aktual di perkebunan karet selain dipengaruhi oleh genetik tanaman, namun dipengaruhi oleh faktor lingkungan serta interaksi genotipe dan lingkungan. Menurut Junaidi et al. (2015), curah hujan dan suhu minimum pada suatu kawasan dapat menjadi faktor utama yang mempengaruhi pola produksi dan pertumbuhan tanaman. Jumlah curah hujan mempengaruhi ketersediaan air tanah yang akan terkait dengan metabolisme tanaman. Kadar air tanah yang rendah merupakan salah satu penyebab tanaman karet menggugurkan daunnya sehingga mengakibatkan penurunan laju aliran lateks. Kondisi tersebut menyebabkan hasil lateks tanaman karet menjadi rendah (Ardika et al., 2011).

Respon klon karet terhadap perubahan pola curah hujan adalah dengan cara menggugurkan daunnya pada saat memasuki bulan kering. Hal tersebut dilakukan sebagai antisipasi tanaman karet secara fisiologi menanggapi ketidakcukupan air pada proses transpirasi (Siregar et al., 2007; Gireesh et al., 2011). Menurut Larcher (1995), gugur daun merupakan aklimatisasi tanaman saat bulan kering dan berfungsi menjaga homeostatik untuk mempertahankan keseimbangan antara tajuk tanaman dengan bagian tanaman lain serta sebagai penyeimbang antara tanaman dengan lingkungan abiotik.

Setiap klon karet memiliki respon yang berbeda terhadap waktu dan lama menggugurkan daunnya. Menurut Morgan (1984), gugur daun pada suatu tanaman terdiri atas 3 tahap, yaitu 1) inisiasi perontokan daun melalui signal internal perontokan, 2) induksi perontokan daun melalui sintesis hormon daun, dan 3) perontokan daun yang didahului oleh perubahan biokimia, anatomi dan fisiologi tanaman. Gugur daun tersebut dapat terjadi secara serentak maupun secara bertahap.

Pada tanaman karet, siklus perkembangan daun dapat dikelompokkan menjadi lima fase yaitu: fase 1 ditandai dengan munculnya tanda-tanda daun menguning sebagian; fase 2 ditandai dengan daun dalam kondisi kuning menyeluruh dan sebagian sudah gugur; fase 3 ditandai dengan seluruh daun sudah gugur dan mulai muncul kuncup daun berwarna cokelat; fase 4 ditandai dengan daun mulai berwarna hijau muda; dan fase 5 ditandai dengan daun berwarna hijau tua. Kondisi perubahan pola gugur daun tersebut sebagai penyebab hasil karet pada klon tertentu menjadi berfluktuasi (Oktavia dan Lasminingsih, 2010).

Aktifitas seleksi dan pemuliaan tanaman karet telah menghasilkan berbagai klon karet unggul komersial maupun klon karet harapan yang masih dalam tahap pengujian yang salah satunya adalah klon karet harapan yang ada di pengujian Plot Promosi PP/07/04. Dari hasil evaluasi selama enam tahun memperlihatkan beberapa genotipe memiliki potensi daya hasil tinggi, namun belum diketahui respon tanaman terhadap perubahan lingkungan terutama kondisi cekaman kekeringan yang menyebabkan terjadinya perubahan fase perdaunan. Diperolehnya genotipe karet unggul yang berdaya hasil tinggi dan stabil pada perubahan kondisi lingkungan merupakan harapan bagi pemulia tanaman karet. Tujuan penelitian ini adalah untuk mengetahui keragaman hasil lateks beberapa genotipe karet harapan di pengujian Plot Promosi 
PP/07/04 akibat terjadinya dinamika gugur daun.

\section{Bahan dan Metode}

Penelitian ini dilakukan pada bulan Agustus 2015 - Maret 2016 di Kebun Percobaan Balai Penelitian Sungei Putih, Pusat Penelitian Karet yang terletak pada ketinggian $54 \mathrm{~m}$ di atas permukaan laut. Klasifikasi jenis tanah digolongkan ke dalam tanah ultisol. Rata-rata curah hujan sepuluh tahun terkahir adalah sebesar 2005 $\mathrm{mm} /$ tahun. Materi genetik yang digunakan pada penelitian ini sebanyak 15 genotipe karet harapan berasal dari hasil perilangan 1992 pada umur 11 tahun, yaitu: genotype nomer HP 92/109, HP 92/179, HP 92/211, HP 92/309, HP 92/327, HP 92/366, HP 92/368, HP 92/388, HP 92/542, HP 92/669, HP 92/677, HP 92/704, HP 92/ 711, HP 92/726, HP 92/838 serta 2 klon pembanding PB 260 dan RRIC 100. Penelitian ini dirancang menggunakan rancangan acak lengkap (RAL) faktorial dengan tiga ulangan.
Faktor pertama adalah genotipe karet harapan hasil persilangan 1992 yaitu sebanyak 15 genotipe dan 2 klon pembanding. Masing-masing genotipe dan klon pembanding terdiri dari 60 tanaman yang setiap ulangan terdiri atas 20 tanaman. Faktor kedua adalah faktor kondisi fase daun yang terdiri dari 5 fase perdaunan yaitu: fase 1 ditandai dengan mulai muncul tanda-tanda daun menguning sampai kuning sebagian, fase 2 ditandai dengan daun dalam kondisi kuning menyeluruh dan sebagian sudah gugur, fase 3 ditandai dengan semua daun gugur dan muncul kuncup daun berwarna cokelat, fase 4 ditandai dengan daun mulai berwarna hijau muda, dan fase 5 ditandai dengan kondisi daun berwarna hijau tua (Gambar 1) (Oktavia dan Lasminingsih, 2010). Tanaman yang diamati pada penelitian ini sebanyak 5 tanaman pada setiap ulangan. Pengamatan terhadap kondisi perdaunan memperlihatkan semua genotipe dan klon pembanding yang diamati mengalami semua fase perdaunan (fase 1 sampai dengan fase 5).

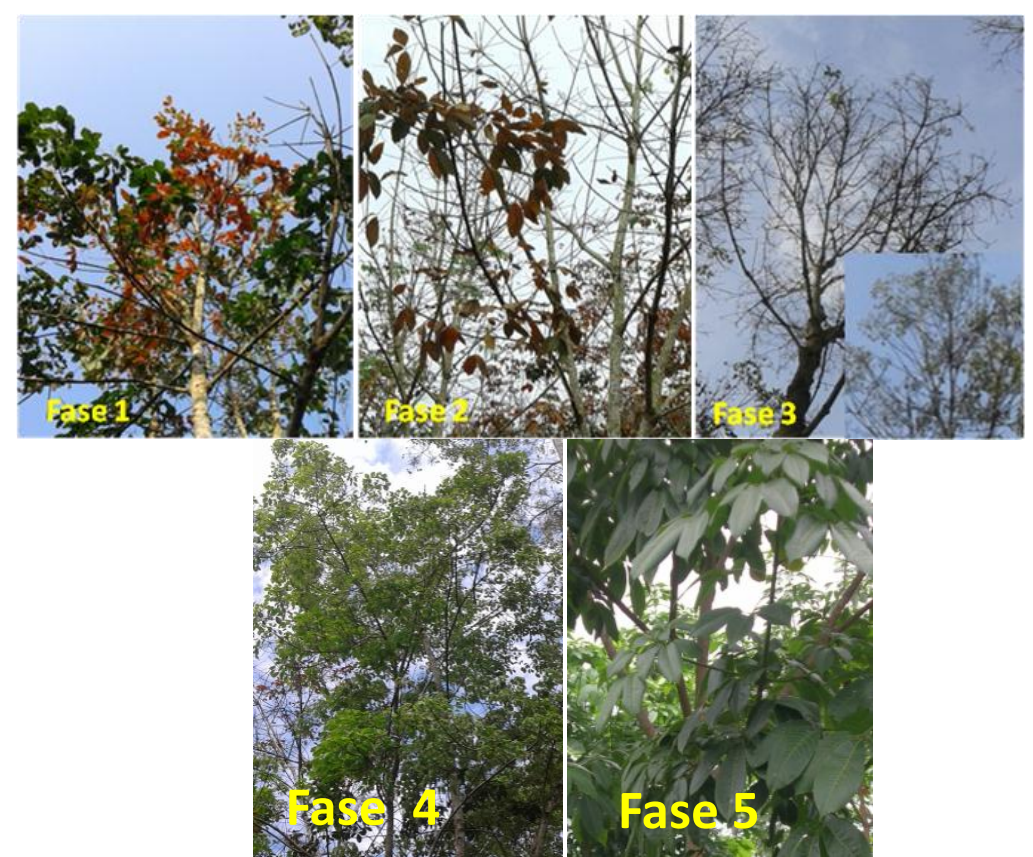

Gambar 1. Fase perkembangan perdaunan tanaman karet 
Variabel yang diamati pada penelitian ini adalah hasil lateks masing-masing genotipe sesuai dengan kondisi fase perdaunan. Pengamatan hasil lateks menggunakan sistem sadap S/2 d3. Data hasil pengamatan dianalisis dengan menggunakan analisis ragam menurut rancangan acak lengkap
(RAL) faktorial. Jika perlakuan menunjukkan pengaruh nyata maka dilakukan uji lanjut menggunakan uji Tukey. Sumber keragaman rancangan acak lengkap (RAL) faktorial disajikan pada Tabel 1 (Mattjik dan Sumertajaya, 2006).

Tabel 1. Model sidik ragam rancangan acak lengkap (RAL) dua faktor

\begin{tabular}{lcccc}
\hline Sumber keragaman & $\mathrm{db}$ & $\mathrm{JK}$ & $\mathrm{KT}$ & F hitung \\
\hline Genotipe (G) & $\mathrm{g}-1$ & $\mathrm{JKG}$ & $\mathrm{KTG}$ & KTG/KTE \\
Fase daun (F) & $\mathrm{m}-1$ & $\mathrm{JKF}$ & $\mathrm{KTF}$ & KTF/KTE \\
Gx F & $(\mathrm{g}-1)(\mathrm{f}-1)$ & $\mathrm{JKGxF}$ & KTGxF & KTGxF/KTE \\
Galat & $\mathrm{e}-1$ & $\mathrm{JKE}$ & $\mathrm{KTE}$ & \\
\hline Total & gfr-1 & & & \\
\hline
\end{tabular}

Untuk mengetahui keragaman hasil lateks dalam genotipe pada setiap fase perdaunan masing-masing genotipe, maka dilakukan analisis dengan menggunakan statistik sederhana memanfaatkan program software Minitab ver. 16 untuk mendapatkan nilai ragam $(\sigma)$, simpangan baku (sd), dan koefisien keragaman (KK) pada masingmasing genotipe terhadap kelima fase perdaunan. Stabilitas hasil yang tinggi dari suatu genotipe ditandai dengan nilai ragam dan koefisien keragaman dalam genotipe rendah (homogenitas tinggi). Menurut Suratman et al.(2000), keragaman tanaman dapat dibedakan menjadi empat tingkatan yaitu (1) homogen apabila koefisien keragaman $0 \%,(2)$ relatif homogen apabila nilai koefisien keragaman $0,1-25 \%$, (3) relatif heterogen apabila nilai koefisien keragaman $25,1-50 \%$, dan (4) heterogen apabila nilai koefisien keragaman $>50 \%$.

\section{Hasil dan Pembahasan}

Tanaman karet memiliki sifat menggugurkan daun pada setiap musim kemarau. Priyadarshan et al. (2001) menjelaskan bahwa gugur daun terjadi seiring adanya perubahan pola curah hujan bulanan. Kondisi curah hujan rendah mengakibatkan tanaman karet menggugurkan daun secara alami sebagai respon terhadap cekaman kekeringan yang terjadi pada bulan-bulan kering setiap tahunnya. Kondisi jumlah curah hujan dan hari hujan bulanan yang diamati pada saat penelitian di lokasi pengujian disajikan pada Gambar 2, sedangkan kondisi kelembaban udara dan suhu udara disajikan pada Gambar 3. 


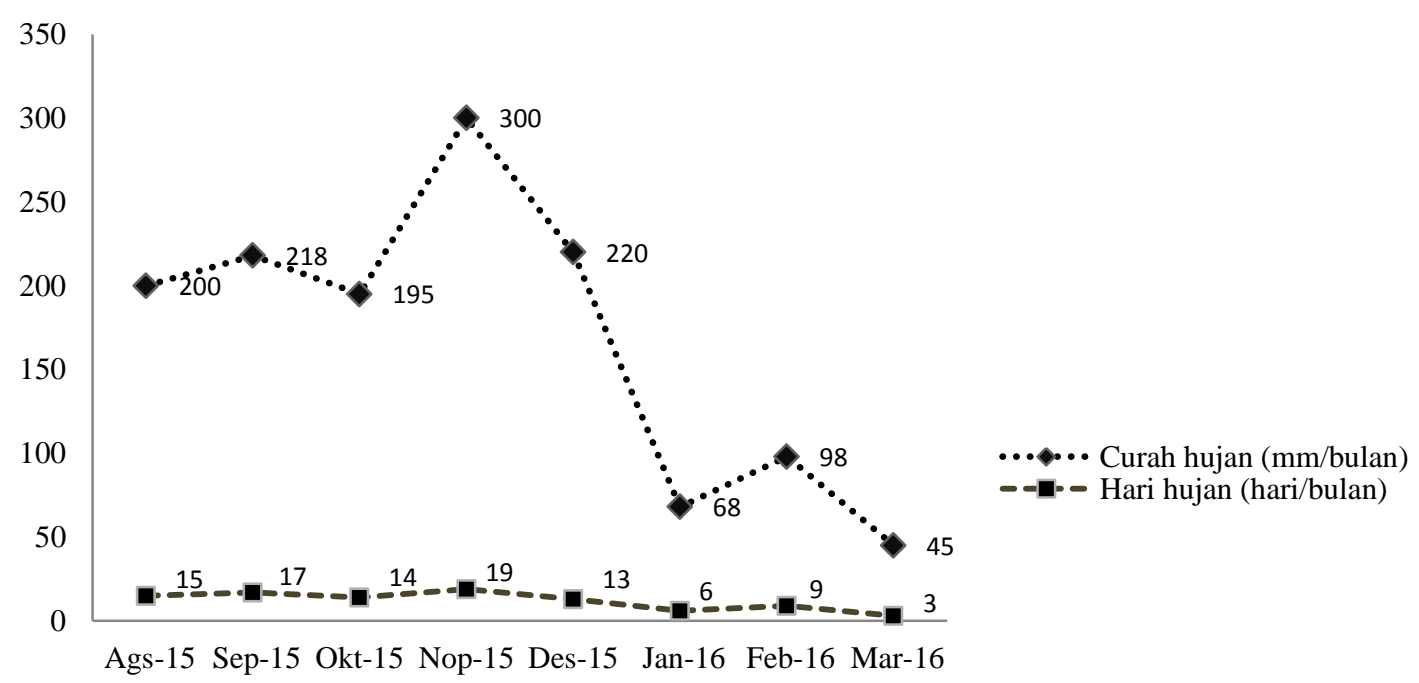

Gambar 2. Kondisi jumlah curah hujan dan hari hujan pada bulan Agustus 2015 - Maret 2016 di lokasi penelitian.

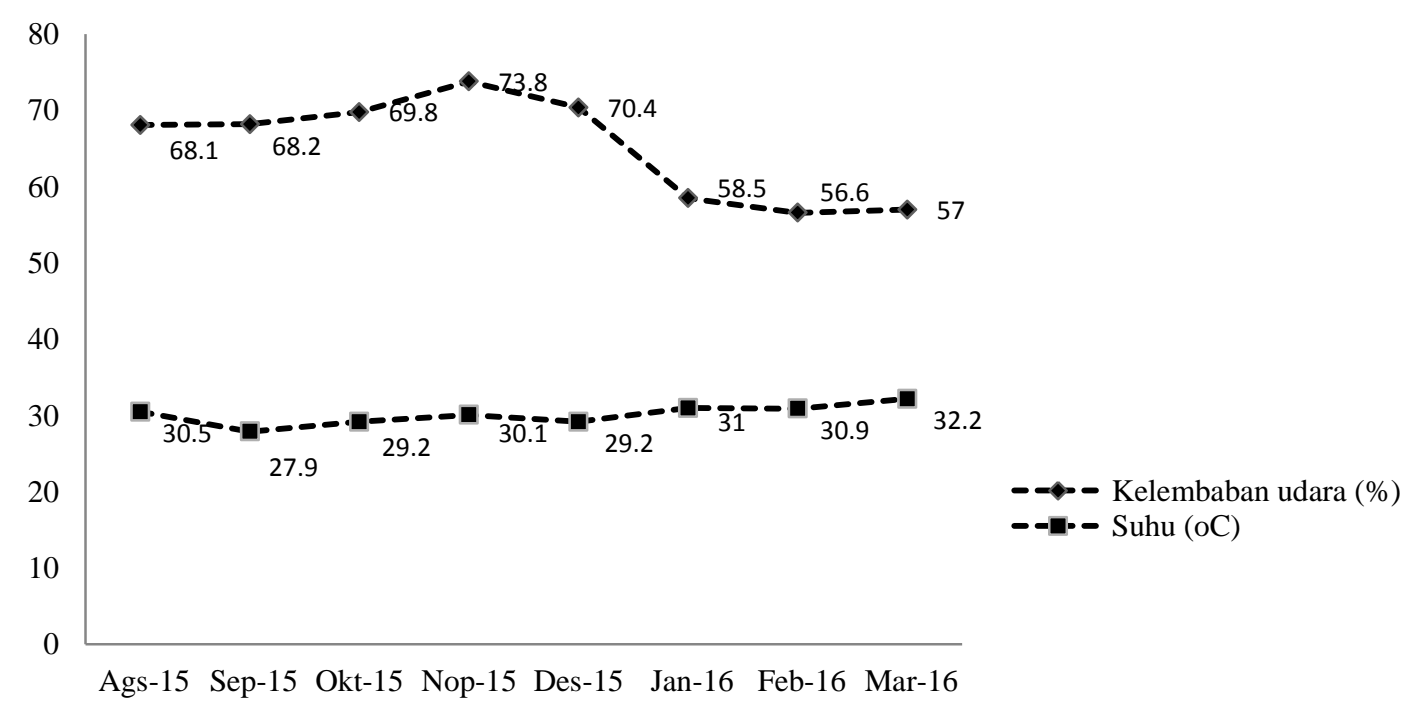

Gambar 3. Kondisi kelembaban udara dan suhu udara pada bulan Agustus 2015 - Maret 2016 di lokasi penelitian.

Gugur daun tanaman karet terjadi sejalan dengan perubahan pola curah hujan. Menurut Siregar (2008), kondisi curah hujan rendah tanaman karet secara alami beradaptasi dengan cara menggugurkan daunnya, hal ini dilakukan sebagai antisipasi fisiologi tanaman menanggapi cekaman kekeringan pada saat bulan kering. Sejalan dengan perubahan curah hujan, maka daun- daun tanaman tumbuh kembali dan selanjutnya daun-daun tersebut berfungsi kembali sebagai sumber asimilat bagi pertumbuhan tajuk dan pembentukan lateks (Siregar, 2014). Perubahan kondisi curah hujan dan pola gugur daun tersebut diduga akan mempengaruhi respon masing-masing genotipe terhadap pertumbuhan dan hasil lateks. 
Hasil pengamatan secara langsung di lokasi penelitian diawali pada saat kondisi daun masuk pada fase 5 yang terjadi pada bulan Agustus - Oktober 2015, kondisi daun fase 1 terjadi pada bulan November 2015, fase 2 terjadi pada bulan Desember 2015, fase 3 terjadi pada bulan Januari - Februari 2016, dan fase 4 terjadi pada bulan Maret 2016. Kondisi perdaunan fase 1, 2, dan 5 terjadi pada bulan Agustus - Desember 2015 dimana kondisi curah hujan tergolong tinggi $>200 \mathrm{~mm} /$ bulan, kecuali pada bulan Oktober 2015, sedangkan fase 3 dan 4 terjadi pada bulan Januari - Maret 2016 dimana kondisi curah hujan tergolong rendah $<100$ $\mathrm{mm} /$ bulan. Perubahan pola curah hujan tersebut menyebabkan klon karet memiliki respon yang berbeda terhadap hasil lateks. Analisis ragam daya hasil lateks beberapa genotipe karet harapan terhadap perubahan fase perdaunan disajikan pada Tabel 2. Hasil analisis ragam daya hasil lateks 15 genotipe menunjukkan bahwa genotipe, fase perdaunan, dan interaksinya berbeda nyata pada $\alpha 0,01$ menurut uji $\mathrm{F}$.

Tabel 2. Sidik ragam daya hasil lateks terhadap kondisi fase gugur daun 15 genotipe karet harapan dari hasil persilangan 1992 di pengujian Plot Promosi .

\begin{tabular}{cccccc}
\hline Sumber keragaman & $\mathrm{db}$ & $\mathrm{JK}$ & $\mathrm{KT}$ & F hitung & $\mathrm{P}$ \\
\hline Genotipe & 16 & $19.011,74$ & $1.188,23^{* *}$ & 46,81 & 0,00 \\
Fase daun & 4 & $10.493,52$ & $2.623,38^{* *}$ & 103,35 & 0,00 \\
Genotipe x Fase daun & 64 & $3.131,05$ & $48,92^{* *}$ & 1,93 & 0,00 \\
Galat & 170 & $4.315,05$ & 25,38 & & \\
\hline Total & 254 & $36.951,36$ & & & \\
\hline
\end{tabular}

Keterangan: tanda $* ; * *=$ berturut-turut berbeda nyata pada $\alpha 0,05$ dan $\alpha 0,01$

Hasil uji lanjut menurut uji Tukey menunjukkan bahwa hasil lateks klon karet berbeda nyata pada kondisi kelima fase perdaunan (Gambar 4). Genotipe nomer HP 92/542 memiliki hasil lateks paling tinggi dan berbeda nyata dengan klon pembanding PB 260 maupun RRIC 100. Genotipe nomer HP 92/677, HP 92/388 dan HP 92/726 memiliki hasil lateks paling rendah dan berbeda nyata dengan klon pembanding $\mathrm{PB}$ 260 maupun RRIC 100. Demikian halnya dengan analisis uji lanjut interaksi genotipe dan fase perdaunan menunjukkan berbeda nyata antar genotipe (Tabel 3). Genotipe nomer HP 92/542 memiliki hasil lateks paling tinggi pada fase 1 , namun tidak berbeda nyata dengan klon pembanding $\mathrm{PB}$ 260. Genotipe HP 92/542 pada fase 2, 3, 4 dan 5 memiliki hasil lateks lebih tinggi dibandingkan dengan genotipe lainnya maupun klon pembanding PB 260 dan RRIC 100 , namun terjadi penurunan hasil lateks seiring dengan perubahan fase gugur daun terutama pada fase 2,3 , dan 4 . 


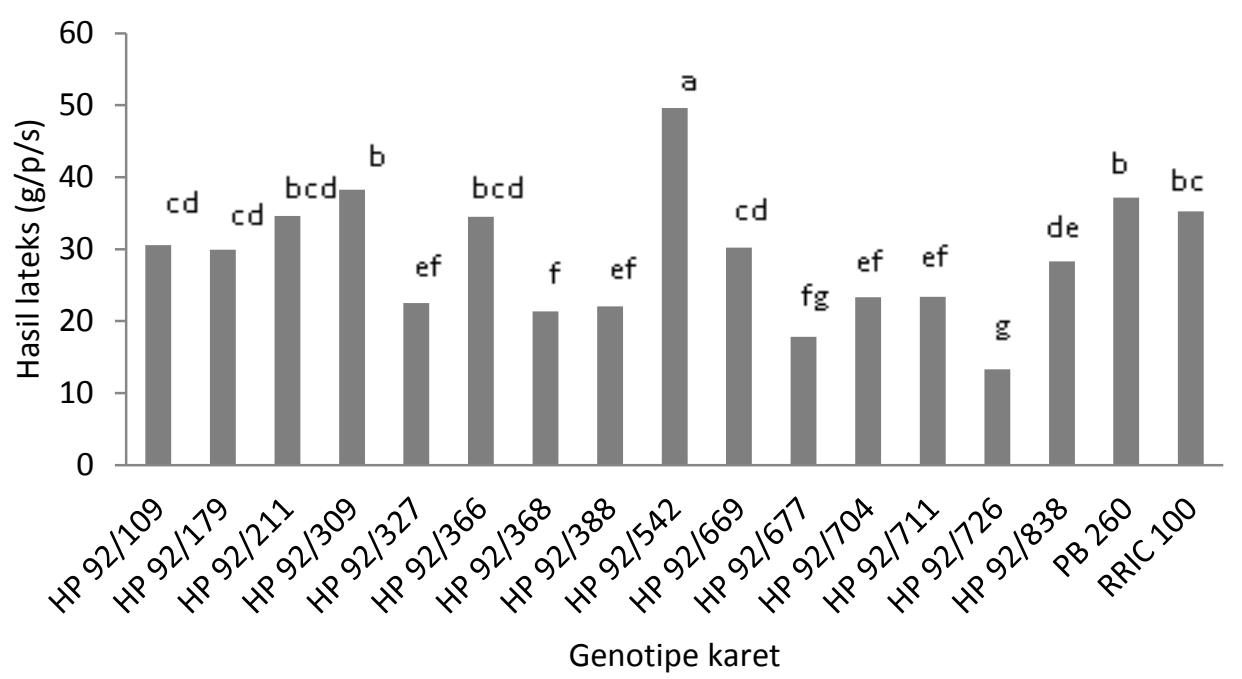

Gambar 4. Rerata hasil lateks dari lima fase perdaunan 15 genotipe karet harapan dari hasil persilangan 1992 di pengujian Plot Promosi PP/07/04.

Genotipe HP 92/309 memiliki hasil lateks cukup berfluktuasi pada setiap fase, namun hasil lateksnya masih lebih tinggi dibandingkan dengan klon pembanding $\mathrm{PB}$ 260 dan RRIC 100, kecuali pada fase 4. Sejalan dengan terbentuknya daun sempurna (fase 5) hasil lateks genotipe HP 92/309 meningkat secara nyata dibandingkan dengan kondisi fase-fase daun sebelumnya dan lebih tinggi dibandingkan dengan klon pembanding PB 260 maupun RRIC 100 dengan persentase sebesar $16,08 \%$ dan $8,31 \%$. Hasil lateks yang tinggi pada genotipe nomer HP 92/309 dan HP 92/542 pada fase 5 diduga karena kondisi daun kedua genotipe sudah tumbuh sempurna, sehingga tanaman dapat melakukan aktifitas fotosintesis berlangsung secara optimal.

Tabel 3.Interaksi genotipe dan fase daun 15 genotipe karet harapan dari hasil persilangan 1992di pengujian Plot Promosi.

\begin{tabular}{|c|c|c|c|c|c|}
\hline \multirow{2}{*}{$\begin{array}{c}\text { Nomer } \\
\text { Genotipe }\end{array}$} & \multicolumn{5}{|c|}{ Hasil lateks (g/p/s) } \\
\hline & Fase 1 & Fase 2 & Fase 3 & Fase 4 & Fase 5 \\
\hline HP 92/109 & $39,22^{\mathrm{a}-\mathrm{m}}$ & $36,65^{b-o}$ & $22,09^{1-x}$ & $22,37^{\mathrm{k}-\mathrm{x}}$ & $32,52^{\mathrm{d}-\mathrm{s}}$ \\
\hline HP 92/179 & $35,31^{b-q}$ & $35,43^{b-q}$ & $21,04^{\mathrm{n}-\mathrm{x}}$ & $17,98^{p-x}$ & $39,80^{a-1}$ \\
\hline HP 92/211 & $42,29^{\mathrm{a}-\mathrm{h}}$ & $37,98^{a-n}$ & $27,34^{\mathrm{f}-\mathrm{w}}$ & $31,98^{\mathrm{d}-\mathrm{s}}$ & $33,41^{\mathrm{c}-\mathrm{r}}$ \\
\hline HP 92/309 & $43,95^{\mathrm{a}-\mathrm{g}}$ & $42,60^{a-h}$ & $31,94^{\mathrm{d}-\mathrm{s}}$ & $21,29^{n-x}$ & $51,48^{\mathrm{abc}}$ \\
\hline HP 92/327 & $28,61^{\mathrm{e}-\mathrm{w}}$ & $25,56^{\mathrm{h}-\mathrm{w}}$ & $13,53^{\mathrm{t}-\mathrm{x}}$ & $11,58^{\mathrm{wx}}$ & $33,33^{\mathrm{c}-\mathrm{r}}$ \\
\hline HP 92/366 & $42,60^{\mathrm{a}-\mathrm{h}}$ & $38,42^{a-n}$ & $23,46^{j-w}$ & $26,57^{\text {f-w }}$ & $41,39^{a-i}$ \\
\hline HP 92/368 & $25,96^{\mathrm{h}-\mathrm{w}}$ & $22,60^{k-x}$ & $15,43^{s-x}$ & $13,19^{u-x}$ & $29,53^{e-v}$ \\
\hline HP 92/388 & $21,85^{\mathrm{m}-\mathrm{x}}$ & $22,14^{1-x}$ & $14,85^{5-x}$ & $26,43^{\mathrm{g}-\mathrm{w}}$ & $24,94^{\mathrm{h}-\mathrm{w}}$ \\
\hline HP 92/542 & $52,95^{\mathrm{ab}}$ & $50,90^{\mathrm{abc}}$ & $45,27^{a-e}$ & $43,88^{a-g}$ & $55,37^{\mathrm{a}}$ \\
\hline HP 92/669 & $35,27^{b-q}$ & $32,56^{\mathrm{d}-\mathrm{s}}$ & $19,40^{o-x}$ & $19,93^{0-x}$ & $43,86^{\mathrm{a}-\mathrm{g}}$ \\
\hline HP 92/677 & $22,09^{1-x}$ & $16,90^{r-x}$ & $12,12^{\mathrm{vwx}}$ & $12,50^{\mathrm{vwx}}$ & $25,44^{\mathrm{h}-\mathrm{w}}$ \\
\hline HP 92/704 & $27,34^{\mathrm{f}-\mathrm{w}}$ & $29,57^{\mathrm{e}-\mathrm{v}}$ & $17,66^{q-x}$ & $13,68^{t-x}$ & $28,35^{\mathrm{e}-\mathrm{w}}$ \\
\hline HP 92/711 & $26,57^{\mathrm{f}-\mathrm{w}}$ & $17,72^{q-x}$ & $16,15^{r-x}$ & $15,70^{r-x}$ & $40,69^{a-j}$ \\
\hline HP 92/726 & $14,91^{s-x}$ & $21,16^{\mathrm{n}-\mathrm{x}}$ & $5,30^{x}$ & $5,53^{\mathrm{x}}$ & $19,50^{0-x}$ \\
\hline
\end{tabular}




\begin{tabular}{|c|c|c|c|c|c|}
\hline HP 92/838 & $40,05^{\mathrm{a}-\mathrm{k}}$ & $24,06^{\mathrm{i}-\mathrm{w}}$ & $20,88^{n-x}$ & $19,71^{0-x}$ & $36,71^{\mathrm{b}-\mathrm{o}}$ \\
\hline RRIC 100 & $38,20^{a-n}$ & $35,43^{b-p}$ & $28,95^{\mathrm{e}-\mathrm{w}}$ & $29,23^{\mathrm{e}-\mathrm{w}}$ & $44,35^{\mathrm{a}-\mathrm{f}}$ \\
\hline PB 260 & $40,02^{a-k}$ & $36,34^{b-o}$ & $30,87^{\mathrm{d}-\mathrm{u}}$ & $30,98^{\mathrm{d}-\mathrm{t}}$ & $47,53^{\mathrm{abcd}}$ \\
\hline
\end{tabular}

Angka-angka pada kolom dan baris yang sama yang diikuti oleh huruf yang sama tidak berbeda nyata pada a 0,05 menurut uji Tukey.

Genotipe nomer HP 92/366, HP 92/669 dan HP 92/711 tergolong peka terhadap perubahan pola gugur daun, hal tersebut terlihat dari hasil lateksnya lebih rendah dibandingkan klon PB 260 pada fase 1, 2, 3, dan 4 , namun saat memasuki fase 5 ternyata tiga genotipe tersebut memiliki hasil lateks cukup tinggi dibandingkan genotipe lainnya. Webster dan Paardekooper (1989) menyatakan gugur daun secara alami merupakan antisipasi fisiologi agar tanaman dapat beradaptasi pada kondisi kekeringan. Sejalan dengan perubahan curah hujan dari musim kering ke musim basah menyebabkan daun-daun tanaman mulai tumbuh menjadi organ sempurna (fase 5) sehingga mampu berfungsi sebagai source untuk menghasilkan asimilat bagi pertumbuhan tajuk dan pembentukan lateks. Fenomena gugur daun tanaman karet terjadi secara ritmik periodik setiap tahunnya (Siregar et al., 2007).

Hasil analisis uji lanjut menunjukkan bahwa kondisi fase daun tanaman memberikan pengaruh nyata terhadap hasil lateks (Gambar 5.). Hasil lateks (g/p/s) paling tinggi terjadi pada kondisi daun fase 5 $(36,95 \mathrm{~g})$, sedangkan paling rendah terjadi pada kondisi daun fase $3(21,55 \mathrm{~g})$ dan fase 4 $(21,33 \mathrm{~g})$. Kondisi daun fase 1 (33,93 g) tidak berbeda nyata dengan fase $2(30,94 \mathrm{~g})$, namun kondisi fase 2 berbeda nyata dengan fase 5 sedangkan fase 1 tidak berbeda nyata dengan fase 5 . Demikian halnya antara fase 5 dengan fase 3 dan fase 4 menunjukkan perbedaan nyata. Perbedaan hasil lateks antara fase 5 dengan fase 3 dan fase 4 masing-masing sebesar $71,46 \%$ dan $73,23 \%$.

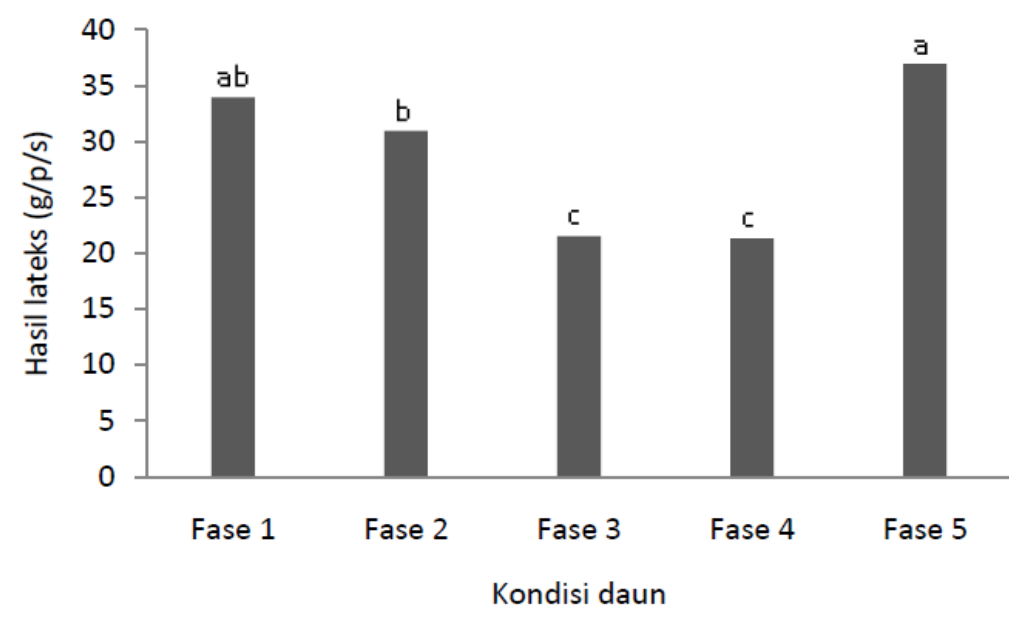

Gambar 5. Rerata hasil lateks berdasarkan kondisi daun 15 genotipe karet harapan dari hasil persilangan 1992 di pengujian Plot Promosi PP/07/04. 
Menurut Junaidi et al. (2015) hasil lateks yang rendah tidak hanya disebabkan oleh gugur daun, namun fungsi daun sangat penting pada proses fotosintesis untuk menghasilkan asimilat sebagai bahan baku biosintesis lateks. Hasil lateks tinggi umumnya diperoleh pada kondisi daun penuh dengan penyinaran dan kadar air tanah yang optimal (Miguel et al., 2007). Pada kondisi kecukupan air dan kondisi daun penuh tersebut maka laju fotosintesis akan berjalan efektif, sehingga dapat menghasilkan asimilat maksimal dan selanjutnya akan berdampak pula terhadap peningkatan hasil lateks (Vinod et al., 2010).

Hasil lateks akan cenderung menurun pada saat menjelang gugur daun yakni pada kondisi daun tanaman mulai memasuki gejala dan menguning dan pada akhirnya memasuki fase gugur daun total. Penurunan hasil lateks terjadi puncaknya pada kondisi semua daun telah gugur dan tanaman membentuk tunas dan daun baru. Penggunaan energi yang besar untuk membentuk tunas dan daun baru menyebabkan sintesis partikel karet terhambat. Produksi lateks secara perlahan akan meningkat setelah daun terbentuk dan berkembang menjadi daun tua yang sempurna (Thomas dan Boerhendhy, 1988).

Oktavia dan Lasminingsih (2010) menyatakan fluktuasi hasil lateks sangat dipengaruhi oleh kondisi daun tanaman yang erat kaitannya dengan pola curah hujan bulanan. Gugur daun penting dalam homeostatik untuk mempertahankan keseimbangan antara tajuk dengan bagian tanaman lain dan keseimbangan tanaman dengan lingkungan (Siregar et al., 2007; Gunasekera et al., 2013). Pengaruh kondisi daun pada setiap fase terhadap hasil lateks 15 genotipe karet disajikan pada Gambar 6.

Menurut Nurcahyo et al.(2011), turunnya kadar air tanah pada saat musim kemarau mempengaruhi penyerapan air dan unsur hara tanaman yang selanjutnya akan mempengaruhi metabolisme dan pertumbuhan tanaman. Salah satu fungsi utama air bagi tanaman adalah mempertahankan turgiditas sel dan jaringan tanaman yang penting bagi kelangsungan aktivitas sel dalam pembelahan dan pemanjangan sel. Tanaman yang memiliki kecukupan air lebih efektif dalam kegiatan fotosintesis untuk menghasilkan asimilat (Nurcahyo et al., 2011).

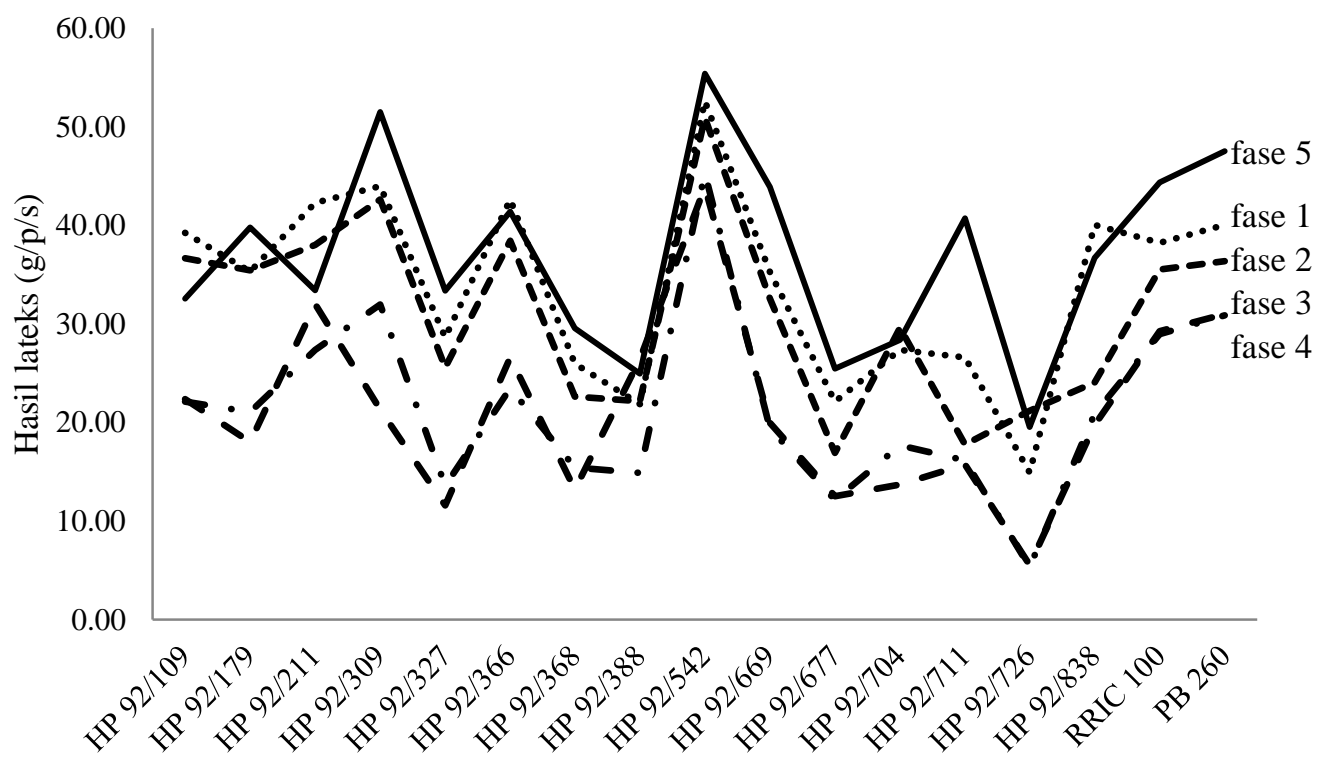

Gambar 6. Pengaruh kondisi daun pada setiap fase terhadap hasil lateks 15 genotipe karet harapan dari hasil persilangan 1992 di pengujian Plot Promosi PP/07/04 
Kramer (1983) menyatakan bahwa pengaruh langsung yang terjadi akibat kekurangan air berkepanjangan yaitu berkurangnya laju pertumbuhan, sehingga ukuran tanaman dan hasil lateks rendah dibandingkan saat tanaman dalam kondisi normal. Thomas dan Boerhendhy (1988) menyatakan kekurangan air pada saat musim kemarau menyebabkan tanaman karet beradaptasi dengan cara menggugurkan daunnya. Hal ini menyebabkan kapasitas fotosintesis tanaman karet menurun, sehingga hasil lateksnya juga menurun.

Penurunan hasil lateks terjadi secara nyata pada saat pembentukan kuncup daun (kondisi fase 3) dan daun muda (kondisi fase 4). Hasil lateks yang rendah pada fase tersebut diduga disebabkan sukrosa yang terdapat pada tanaman lebih diutamakan untuk pertumbuhan tanaman dibandingkan untuk mensintesis partikel karet. Kondisi fase gugur daun mempengaruhi hasil lateks menjadi beragam. Kondisi daun pada fase 3 dan 4 yang menunjukkan hasil lateks yang paling rendah. Hal tersebut disebabkan asimilat digunakan dalam pembentukan kuncup daun dan daun muda (inisiasi daun). Tindakan agronomi yang dapat dilakukan untuk meningkatkan hasil lateks salah satunya adalah dengan cara melakukan aplikasi pemupukan yang terkait dengan pertumbuhan daun pada saat memasuki stadia daun fase 3 dan fase 4. Aplikasi pemupukan terutama yang mengandung unsur hara nitrogen diharapkan dapat mempercepat pemulihan daun membentuk daun sempuna. Menurut Munthe (2007) pemberian pupuk yang paling tepat pada saat tanaman sedang membentuk tunas baru dengan menggunakan pupuk mengandung unsur $\mathrm{N}$.

Kondisi gugur daun yang menjadi penyebab hasil lateks yang beragam pada masing-masing genotipe, maka diperlukan seleksi terhadap genotipe yang memiliki stabilitas hasil lateks tinggi pada semua fase gugur daun. Genotipe stabil dicirikan oleh nilai ragam dan koefisien keragaman yang rendah (Syukur et al., 2012).Dengan demikian, genotipe yang memiliki hasil lateks tinggi dan nilai ragam genotipe dan koefisien keragaman yang rendah sangat diharapkan. Nilai ragam, standar deviasi, dan koefisien keragaman (KK) dalam genotipe pada masing-masing fase gugur daun 15 genotipe karet disajikan pada Tabel 4. 
Tabel 4. Nilai ragam $\left(\sigma^{2}\right)$, standar deviasi (sd), dan koefisien keragaman (KK) dalam genotipe pada masing-masing fase gugur daun 15 genotipe karet harapan hasil persilangan 1992 di pengujian Plot Promosi.

\begin{tabular}{|c|c|c|c|c|c|c|c|c|c|c|c|c|c|c|c|c|c|c|c|c|}
\hline \multirow[b]{2}{*}{$\begin{array}{l}\text { Nomer } \\
\text { Genotipe }\end{array}$} & \multicolumn{4}{|c|}{ Fase 1} & \multicolumn{4}{|c|}{ Fase 2} & \multicolumn{4}{|c|}{ Fase 3} & \multicolumn{4}{|c|}{ Fase 4} & \multicolumn{4}{|c|}{ Fase 5} \\
\hline & $\begin{array}{l}\text { Rataan } \\
(\mathrm{g} / \mathrm{p} / \mathrm{s})\end{array}$ & $\sigma^{2}$ & sd & KK & $\begin{array}{l}\text { Rataan } \\
(\mathrm{g} / \mathrm{p} / \mathrm{s})\end{array}$ & $\sigma^{2}$ & sd & KK & $\begin{array}{l}\text { rataan } \\
(\mathrm{g} / \mathrm{p} / \mathrm{s})\end{array}$ & $\sigma^{2}$ & sd & KK & $\begin{array}{l}\text { rataan } \\
(\mathrm{g} / \mathrm{p} / \mathrm{s}\end{array}$ & $\sigma^{2}$ & sd & KK & $\begin{array}{l}\text { rataan } \\
(\mathrm{g} / \mathrm{p} / \mathrm{s}\end{array}$ & $\sigma^{2}$ & sd & KK \\
\hline HP 92/109 & 39,22 & 117,73 & 10,85 & 27,67 & 36,65 & 267,87 & 16,37 & 44,66 & 22,09 & 73,23 & 8,56 & 38,74 & 22,37 & 101,25 & 10,06 & 44,98 & 32,52 & 28,51 & 5,34 & 16,42 \\
\hline HP 92/179 & 35,31 & 79,04 & 8,89 & 25,18 & 35,43 & 130,73 & 11,43 & 32,27 & 21,04 & 18,71 & 4,33 & 20,56 & 17,98 & 37,56 & 6,13 & 34,09 & 39,80 & 98,84 & 9,94 & 24,98 \\
\hline HP $92 / 211$ & 42,29 & 121,29 & 11,01 & 26,04 & 37,98 & 208,30 & 14,43 & 38,00 & 27,34 & 36,61 & 6,05 & 22,13 & 31,98 & 118,47 & 10,88 & 34,03 & 33,41 & 69,76 & 8,35 & 25,00 \\
\hline HP 92/309 & 43,95 & 14,33 & 3,78 & 8,61 & 42,6 & 125,32 & 10.34 & 24,28 & 31,94 & 21,50 & 4,64 & 14,52 & 21,29 & 24,77 & 4,98 & 23,37 & 51,48 & 58,83 & 7,67 & 14,90 \\
\hline HP $92 / 327$ & 28,61 & 82,62 & 9,09 & 31,77 & 25,56 & 122,85 & 11,08 & 43,36 & 13,53 & 50,38 & 7,10 & 52,46 & 11,58 & 102,60 & 10,13 & 87,47 & 33,33 & 124,31 & 11,15 & 33,45 \\
\hline HP 92/366 & 42,60 & 165,82 & 12,88 & 30,23 & 38,42 & 304,24 & 17,44 & 45,40 & 23,46 & 29,96 & 5,47 & 23,33 & 26,57 & 92,25 & 9,60 & 36,15 & 41,39 & 108,79 & 10,43 & 25,20 \\
\hline HP 92/368 & 25,96 & 147,53 & 12,15 & 46,79 & 22,6 & 123,83 & 11,13 & 49,24 & 15,43 & 52,43 & 7,24 & 46,93 & 13,19 & 26,46 & 5,14 & 39,00 & 29,53 & 226,41 & 15,05 & 50,96 \\
\hline HP 92/388 & 21,85 & 67,37 & 8,21 & 37,57 & 22,14 & 97,88 & 9,89 & 44,68 & 14,85 & 133,82 & 11,57 & 77,90 & 26,43 & 126,21 & 11,23 & 42,51 & 24,94 & 57,65 & 7,59 & 30,44 \\
\hline HP $92 / 542$ & 52,95 & 26,59 & 5,16 & 9,74 & 50,90 & 145,40 & 12,06 & 23,69 & 45,27 & 79,53 & 8,92 & 19,70 & 43,88 & 94,68 & 9,73 & 22,17 & 55,37 & 66,59 & 8,16 & 14,74 \\
\hline HP 92/669 & 35,27 & 17,08 & 4,13 & 11,72 & 32,56 & 90,45 & 9,51 & 29,21 & 19,40 & 18,45 & 4,30 & 22,14 & 19,93 & 38,26 & 6,19 & 31,04 & 43,86 & 59,37 & 7,71 & 17,57 \\
\hline HP 92/677 & 22,09 & 24,58 & 4,96 & 22,44 & 16,90 & 69,14 & 8,32 & 49,20 & 12,12 & 40,45 & 6,36 & 52,47 & 12,50 & 92,70 & 9,63 & 77,03 & 25,44 & 17,99 & 4,24 & 16,67 \\
\hline HP 92/704 & 27,34 & 58,11 & 7,62 & 27,88 & 29,57 & 147,66 & 12,15 & 41,09 & 17,66 & 256,75 & 16,02 & 90,73 & 13,68 & 60,77 & 7,80 & 56,98 & 28,35 & 70,13 & 8,37 & 29,54 \\
\hline HP 92/711 & 26,57 & 33,14 & 5,76 & 21,67 & 17,72 & 214,94 & 14,66 & 82,74 & 16,15 & 32,31 & 5,68 & 35,20 & 15,70 & 31,40 & 5,60 & 35,69 & 40,69 & 364,14 & 19,08 & 46,90 \\
\hline HP 92/726 & 14,91 & 2,35 & 1,53 & 10,28 & 21,16 & 96,38 & 9,82 & 46,40 & 5,30 & 6,53 & 2,56 & 48,23 & 5,53 & 8,80 & 2,97 & 53,66 & 19,50 & 5,34 & 2,31 & 11,85 \\
\hline HP $92 / 838$ & 40,05 & 119,95 & 10,95 & 27,35 & 24,06 & 84,68 & 9,20 & 38,25 & 20,88 & 58,58 & 7,65 & 36,66 & 19,71 & 64,55 & 8,03 & 40,76 & 36,71 & 37,41 & 6,12 & 16,66 \\
\hline PB 260 & 38,20 & 10,33 & 3,21 & 8,41 & 35,43 & 5,90 & 2,43 & 6,86 & 28,95 & 7,64 & 2,76 & 9,55 & 29,23 & 19,03 & 4,36 & 14,92 & 44,35 & 15,93 & 3,99 & 9,00 \\
\hline RRIC 100 & 40,02 & 117,73 & 10,85 & 27,67 & 36,34 & 5,57 & 2,36 & 6,50 & 30,87 & 42,85 & 6,55 & 21,20 & 30,98 & 40,63 & 6,37 & 20,58 & 47,53 & 134,00 & 11,58 & 24,35 \\
\hline Rataan & 33,95 & & & 22,61 & 30,94 & & & 38,11 & 21,55 & & & 37,20 & 21,33 & & & 40,85 & 36,95 & & & 24,04 \\
\hline
\end{tabular}




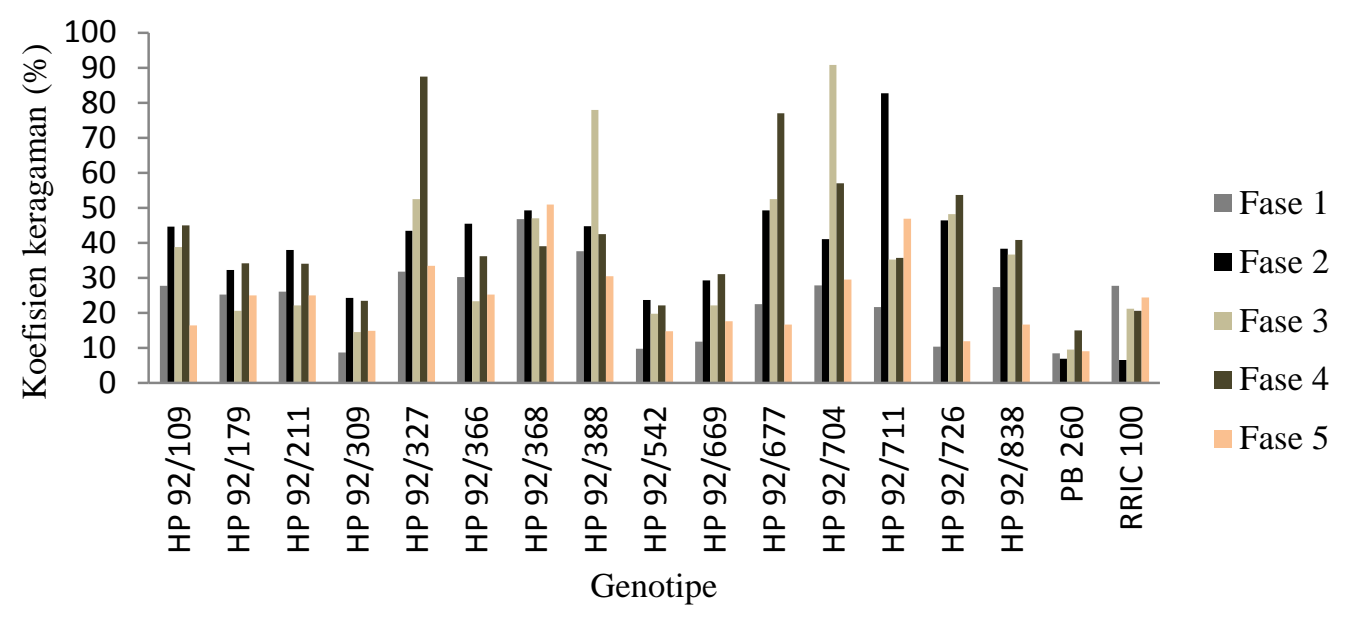

Gambar 7. Nilai koefisien keragaman 15 genotipe karet harapan hasil persilangan 1992 di pengujian Plot Promosi dari kelima fase perdaunan.

Tabel 4 menunjukkan bahwa Genotipe nomer HP 92/309, HP 92/542, dan klon PB 260 memiliki hasil lateks paling tinggi dan diikuti oleh nilai ragam dan koefisien keragaman dalam genotipe paling rendah pada semua fase perdaunan dengan $\mathrm{KK}$ $<25 \%$. Menurut Suratman et al. (2000), homogenitas tanaman tergolong relatif rendah jika memiliki koefisien keragaman antara 0,1-25\%. Genotipe nomer HP 92/368 dan HP 92/388 memiliki nilai koefisien keragaman dalam genotipe tergolong tinggi dengan KK sebesar $>30 \%$ pada semua fase perdaunan, sedangkan genotipe nomer HP 92/327, HP 92/388, HP 92/677, HP 92/704, HP 92/711 memiliki nilai keragaman dalam genotipe paling tinggi pada fase 3 dan fase 4 dengan nilai $\mathrm{KK}>40 \%$ (Gambar 7). Dengan demikian, genotipe nomer HP 92/542 memiliki stabilitas hasil dalam genotipe tergolong tinggi pada semua fase perdaunan, sehingga genotipe tersebut sangat potensial dikembangkan menjadi genotipe karet unggul berdaya hasil tinggi dan stabil terhadap perubahan fase gugur daun dibandingkan dengan genotipe lainnya.

\section{Kesimpulan}

Berdasarkan uraian di atas dapat disimpulkan bahwa keragaman hasil lateks 15 genotipe karet harapan dari hasil persilangan 1992 sangat dipengaruhi oleh kondisi fase perdaunan yang sejalan dengan perubahan pola curah hujan bulanan. Genotipe nomer HP 92/542 memiliki hasil lateks paling tinggi pada semua fase perdaunan, sedangkan paling rendah terdapat pada genotipe nomer HP 92/677 dan HP 92/726. Berdasarkan kondisi fase perdaunan menunjukkan bahwa rerata hasil lateks paling tinggi terdapat pada saat tanaman dalam kondisi daun penuh. Penurunan hasil lateks secara nyata terjadi pada saat kondisi gugur daun dan pembentukan daun muda dengan persentase penurunan hasil lateks masing-masing adalah $71,46 \%$ dan $73,23 \%$. 


\section{Daftar Pustaka}

Ardika, R., Cahyo A.N., dan Wijaya, T. (2011). Dinamika gugur daun dan produksi berbagai klon karet kaitannya denga kandungan air tanah. Jurnal Penelitian Karet, 29(2), 102-109.

Gireesh, T., Raj, S., Midin, K.K., and Mercykutty, V.C (2011). Rubber yield of certain clones of Hevea brasiliensis and relationship with climate variables. Natural Rubber Research, 24(1), 54-60.

Gunasekera, H.K.L.L., De Costa, W.A.J.M., and Nugawela, A. (2013). Canopy photosynthetic capacity and light respone parameters of Rubber Hevea brasiliensis with reference to exploitation. Current Agriculutre Research Journal.1(1), 1-11. doi : 10.12944/CARJ.1.1.01.

Junaidi, Sembiring, Y.R., dan Siregar, T.H.S. (2015). Pengaruh perbedaan letak geografi terhadap pola produksi tahunan tanaman karet: Faktor penyebab perbedaan pola produksi tahunan tanaman karet. Warta Perkaretan, 34(2), 137-146.

Kramer. (1983). Water relations of plants. Florida:Academic Press Inc.

Larcher, W. (1995). Physiological plant ecology. Berlin : Springer.

Mattjik, A.A., dan Sumertajaya, I.M. (2006). Perancangan percobaan dengan aplikasi $S A S$ dan minitab. Bogor : IPB Press.

Morgan, P.W. (1984). Is ethylene the natural regulator of absiscission? In (eds): Fuchs, $\mathrm{Y}$ and Chultz. Ethylene: Biochemical physiological and applied aspect. Martinus Nijhoff Publish, p231-240.

Miguel A.A., Oliveira, L.E.M., Cairo, P.A.R., and Oliveira, D.M. (2007). Photosynthetic behaviour during the leaf ontogeny of rubber tree clones (Hevea brasiliensis Muell. Arg.), in Lavras, MG. Ciência e Agrotecnologia, 31, 91-97. doi: 10.1590/S1413-70542007000100014.
Munthe H. (2007). Tindakan pemupukan untuk meningkatkan daya tahan tanaman karet terhadap serangan penyakit. Workshop Pengadaan Bahan Tanam Karet Unggul dan Pengenalan Klon Penghasil Lateks, Kayu. Sungei Putih, Agustus 2007.

Nurcahyo, A., Ardika, R., dan Thomas. (2011). Konsumsi air dan produksi karet pada berbagai sistem pengaturan jarak tanam dalam kaitannya dengan kandungan air tanah. Jurnal Penelitian Karet,29(2), 110-117.

Oktavia, F., dan Lasminingsih, M. (2010). Pengaruh kondisi daun tanaman karet terhadap keragaman hasil sadap beberapa klon seri IRR. Jurnal Penelitian Karet. 29(2), 32-40.

Priyadarshan, P.M., Sasikumar, S., and Concalves, D.(2001). Phenological changes in Hevea brasiliensis under differential geo climates. The Planter, 77, 447-481.

Siregar, T.H.S., Tohari, Hartiko, H., dan Karyudi. (2007). Dinamika perontokan dan pohon karet dan hasil lateks: I. Jumlah daun rontok dan hasil lateks. Jurrnal Penelitian Karet, 25(1), 45-58.

Siregar, T.H.S. (2008). Dinamika kerontokan daun pohon karet (Hevea brasiliensis Muell Arg.) dan hasil lateks. Doktor. Disertasi. Universitas Gadjah Mada.

Siregar, T.H.S. (2014). Pola musiman produksi dan gugur daun pada klon $\mathrm{PB}$ 260 dan RRIC 100. Jurnal Penelitian Karet, 32(2), 88-97.

Suratman, Priyanto, D., dan Setyawan, A.D. (2000). Analisis keragaman Ipomoea berdasarkan karakter morfologi. Biodiversitas, 1(2), 72-79.

Syukur, M. , Sujiprihati, S., Yunianti, R. (2012). Teknik pemuliaan tanaman. Jakarta : Penebar Swadaya. 
Vinod, K. K., Rajeswati Meenattoor, J., Nanja Reddy, Y. A., Priyadarshan, P.M., Chaudhuri, D. (2010). Ontogenetic variations in flush development are indicative of low temperature tolerance in Hevea brasiliensis clones. Annals of Forest Research, 53(2), 95- 105.
Wijaya, T. dan Boerhendhy, I. (1988). Hubungan neraca air tanah dengan produksi karet klon GT 1 dan PR 261. Bulletin Perkebunan Rakyat. 4(1), 15-18. 